\title{
Lipid peroxidation status as an index to evaluate the influence of dietary fats on vitamin $E$ requirements of young pigs
}

\author{
BY YAO H. WANG ${ }^{1}$, J. LEIBHOLZ ${ }^{2}$, W. L. BRYDEN ${ }^{3}$ AND D. R. FRASER \\ ${ }^{1}$ CSIRO Division of Human Nutrition, Adelaide, SA 5000, Australia \\ ${ }^{2}$ Willawong, Murringo, NSW 2586, Australia \\ ${ }^{3}$ Department of Animal Science, University of Sydney, Camden, NSW 2570, Australia
}

(Received 11 August 1994 -Revised 3 April 1995 - Accepted 3 May 1995)

\begin{abstract}
The aims of the present study were to establish a suitable criterion for estimating the vitamin $\mathbf{E}$ requirement for young pigs, and to investigate the influence of dietary fats on the requirement of this nutrient. In Expt 1 weaned pigs were given a semi-purified diet supplemented with 0,20 , or $100 \mathrm{mg}$ DL$\alpha$-tocopheryl acetate $/ \mathrm{kg}$. Pigs in Expt 2 were fed on diets containing $10 \mathrm{~g}$ sunflower oil (SO) stripped of vitamin $\mathrm{E} / \mathrm{kg}$ in diets 1 and $2,100 \mathrm{~g} \mathrm{SO} / \mathrm{kg}$ in diets 3 and 4 , and $100 \mathrm{~g}$ tallow/kg in diet 5 . Diets 2,4 and 5 were supplemented with DL- $x$-tocopheryl acetate at $20 \mathrm{mg} / \mathrm{kg}$ for $0-28 \mathrm{~d}$ and $50 \mathrm{mg} / \mathrm{kg}$ for $29-56 \mathrm{~d}$ of the experiment respectively. Results showed that vitamin $\mathbf{E}$ concentrations in plasma and tissues reflected dietary levels of vitamin $\mathbf{E}$. No apparent clinical signs of vitamin $\mathbf{E}$ deficiency were observed, but pigs fed on diets without vitamin $E$ supplementation showed a higher $(P<0.05)$ lipid peroxidation status as indicated by thiobarbituric acid-reactive substances in erythrocytes, and ethane and pentane levels in exhaled gases than those fed on supplemental diets. This indicated that the former was deficient in vitamin E. Data in Expt 1 suggested that supplementation with $20 \mathrm{mg}$ DL- $\alpha$-tocopheryl acetate/kg is adequate for young pigs when the diet contains $30 \mathrm{~g}$ lard/kg. However, results in Expt 2 showed that this level was inadequate when the diet contains $100 \mathrm{~g} \mathrm{SO} / \mathrm{kg}$ or its equivalent to $70 \mathrm{mg}$ polyunsaturated fatty acids (PUFA)/g. Vitamin $\mathbf{E}$ and lipid peroxidation status of pigs were affected by both dietary vitamin $E$ and dietary PUFA. This demonstrates that the requirement for vitamin $E$ in young pigs increases as PUFA levels in the diet increase. The present study shows that lipid peroxidation response of pigs is a suitable index to evaluate vitamin $E$ requirements.
\end{abstract}

Lipid peroxidation: Vitamin $\mathbf{E}$ requirement

It is well known that vitamin $\mathrm{E}$ functions as a biological antioxidant. The fat-soluble nature of this vitamin enables it to reside in biological membranes and to function as a free-radical quencher protecting membrane phospholipids from peroxidation damage. Vitamin E cannot be synthesized by animals and, therefore, its presence in animal tissues reflects dietary origin. Deficiencies of vitamin $E$ result in a wide variety of pathological changes in animal tissues. The main manifestations in pigs of vitamin $E$ deficiency and Se deficiency are dietetic microangiopathy or Mulberry heart disease, hepatosis dietetica, and nutritional myopathy (Moir \& Masters, 1979). Death from vitamin E and Se deficiencies, which is most likely to be seen in weaned pigs, is sporadic but can reach 5-10\% of the herd (Van Vleet \& Kennedy, 1989). It is suggested that mulberry heart disease is particularly related to vitamin E deficiency (Moir \& Masters, 1979; Rice \& Kennedy, 1989).

Vitamin $\mathrm{E}$ requirements of pigs have been extensively studied, and the presently recommended dietary requirement varies from 9 to $30 \mathrm{mg} / \mathrm{kg}$ for young pigs (Agricultural Research Council 1981; Jensen et al. 1988). In many studies establishing requirements, clinical signs of deficiency or mortality are the main assessment criteria, and most 
recommended levels are based on that amount of vitamin $\mathbf{E}$ needed to prevent gross signs of deficiency. Nevertheless, the occurrence of clinical signs of deficiency in pigs may be variable in different experiments because variations in the experimental conditions and in the genotypes of pigs could affect the estimated requirement. Plasma vitamin $\mathrm{E}$ concentration has been shown to be a reliable indicator of dietary intake (Jensen et al. 1988). However, plasma vitamin $\mathrm{E}$ is not always closely associated with the actual lipid peroxidation values (Jensen et al. 1983; Duthie et al. 1989) and, therefore, does not accurately indicate the extent of vitamin E deficiency. A better approach, based on the relationship between vitamin $\mathrm{E}$ and lipids, may be the measurement of lipid peroxidation status in pigs as an index for assessing the degree of vitamin $E$ protection against lipid peroxidation damage and requirement for this vitamin.

The fatty acid profile of animal tissues is affected by both quantity and quality of dietary fat (Marchello et al. 1983; Lin et al. 1989). Changes in fatty acid composition may be accompanied by changes in susceptibility of tissue lipids to free-radical attack. Polyunsaturated fatty acids (PUFA), an important component of biological membranes, are susceptible to such attack because their unsaturated double bonds are inherently unstable. Previous studies indicated that vitamin E deficiency in pigs was accelerated by the addition of highly unsaturated fat to the diet (Lindberg \& Orstadius, 1961; Nafstad \& Tollersrud, 1970). Relatively large amounts of fat $(>50 \mathrm{~g} / \mathrm{kg})$ are frequently added to diets to achieve a high energy content for rapidly growing, young pigs.

The objectives of the present study were to determine whether lipid peroxidation status measured as thiobarbituric acid (TBA)-reaction values in erythrocytes (RBC) and hydrocarbon levels in exhaled gases can be used as indices to assess the requirement of vitamin $\mathrm{E}$ for pigs, and to investigate the effect of different levels of dietary fats on vitamin $E$ requirements and lipid peroxidation status of young pigs.

\section{MATERIALS AND METHODS}

Animals and housing

Cross-bred pigs (Landrace $\times$ Large White) were born to sows fed on a diet without vitamin E supplementation from 1 month before farrowing until the piglets were weaned at $21 \mathrm{~d}$ of age in Expt 1 and 17 days in Expt 2. At weaning, four piglets were allocated to each of three treatment groups in Expt 1, and five treatment groups in Expt 2. Each treatment group contained two males and two females with similar mean body weights. All pigs were reared in individual cages throughout the experimental period of $63 \mathrm{~d}$.

\section{Experimental procedure and diets}

All procedures involving animals were approved by the University of Sydney Animal Care and Ethics Committee before commencement of the experiments, and complied with the Australian Code of Practice for the Care and Use of Animals for Scientific Purposes.

Pigs in Expt 1 were given the basal diet shown in Table 1. The diet was supplemented with either 0,20 or $100 \mathrm{mg}$ DL- $\alpha$-tocopheryl acetate (F. Hoffman-La Roche Co Ltd, Basel, Switzerland)/kg for treatment groups 1, 2 and 3 respectively. Pigs in Expt 2 were given diets containing $10 \mathrm{~g}$ sunflower oil (SO) $/ \mathrm{kg}$ (diets 1 and 2), $100 \mathrm{~g} \mathrm{SO} / \mathrm{kg}$ (diets 3 and 4) or $100 \mathrm{~g}$ tallow $/ \mathrm{kg}$ (diet 5; Table 2). The diets were supplemented with vitamin $\mathrm{E}$ at either 0 (diets 1 and 3) or $20 \mathrm{mg}$ (diets 2, 4 and 5) DL- $\alpha$-tocopheryl acetate/ $\mathrm{kg}$ on days $0-28$ and either 0 or $50 \mathrm{mg} / \mathrm{kg}$ respectively on days $29-56$ of the experiment. In both experiments pigs were allowed ad lib. access to feed and water for $56 \mathrm{~d}$. After this time $\mathrm{Cr}_{2} \mathrm{O}_{3}$ at concentrations of $10 \mathrm{~g} / \mathrm{kg}$ in Expt 1 and $2 \mathrm{~g} / \mathrm{kg}$ in Expt 2 was included in the diets which were then fed hourly to pigs in equal portions for $6 \mathrm{~d}$. 
Table 1. Expt 1. Composition $(\mathrm{g} / \mathrm{kg})$ of the basal diet for pigs*

\begin{tabular}{ll}
\hline \multicolumn{1}{c}{ Ingredients } \\
\hline \\
Maize starch & 630 \\
Casein & 170 \\
Soyabean meal & 100 \\
Dicalcium phosphate & 35 \\
Lard & 30 \\
Calcium stearate $\dagger$ & 20 \\
& 15 \\
\hline
\end{tabular}

* The basal diet contained $0.5 \mathrm{mg} \alpha$-tocopherol $/ \mathrm{kg}$ diet, and the diet was supplemented with 0,20 or $100 \mathrm{mg}$ $\mathrm{DL}-\alpha$-tocopheryl acetate $/ \mathrm{kg}$.

$\uparrow$ Calcium stearate was added to the diet as a pelleting agent.

$\ddagger$ Vitamin + mineral premix $(\mathrm{mg} / \mathrm{kg}$ diet): retinyl acetate $894 \mu \mathrm{g}$, cholecalciferol $6.5 \mu \mathrm{g}$, vitamin $\mathrm{K} 0 \cdot 6$, cyanocobalamin $21 \mu \mathrm{g}$, pyridoxine $1 \cdot 8$, riboflavin $4 \cdot 2$, folic acid $0 \cdot 36$, niacin 18 , pantothenic acid 12 , thiamin $1 \cdot 2$, biotin $60 \mu \mathrm{g}$, choline $0.6 \mathrm{~g}, \mathrm{NaCl} 2 \mathrm{~g}, \mathrm{FeSO}_{4} . \mathrm{H}_{2} \mathrm{O} 0.31 \mathrm{~g}, \mathrm{KCl} 5.6 \mathrm{~g}, \mathrm{ZnSO}_{4} .7 \mathrm{H}_{2} \mathrm{O} \mathrm{0.5} \mathrm{g,} \mathrm{MgO}_{0.7} \mathrm{~g}_{,} \mathrm{Na}_{2} \mathrm{SeO}_{3}$ $0 \cdot 63, \mathrm{NaI} 0 \cdot 19, \mathrm{CuSO}_{4} .5 \mathrm{H}_{2} \mathrm{O} 23 \cdot 8, \mathrm{MnSO}_{4} . \mathrm{H}_{2} \mathrm{O} 1 \cdot 25$.

Table 2. Expt 2. Composition and nutrient content $(\mathrm{g} / \mathrm{kg})$ of diets fed to pigs*

\begin{tabular}{|c|c|c|c|c|c|c|}
\hline \multirow{2}{*}{$\begin{array}{l}\text { Experimental period (d)... } \\
\text { Diet no.... }\end{array}$} & \multicolumn{3}{|c|}{$0-28$} & \multicolumn{3}{|c|}{$29-56$} \\
\hline & 1 and 2 & 3 and 4 & 5 & 1 and 2 & 3 and 4 & 5 \\
\hline \multicolumn{7}{|l|}{ Ingredient } \\
\hline Maize starch & 535 & 445 & 445 & 555 & 465 & 465 \\
\hline Casein & 100 & 100 & 100 & - & - & - \\
\hline Skim milk & 120 & 120 & 120 & 50 & 50 & 50 \\
\hline Meat meal & 100 & 100 & 100 & 100 & 100 & 100 \\
\hline Soyabean meal & 100 & 100 & 100 & 250 & 250 & 250 \\
\hline Sunflower oil & 10 & 100 & - & 10 & 100 & - \\
\hline Tallow & - & - & 100 & - & - & 100 \\
\hline Calcium stearate & 20 & 20 & 20 & 20 & 20 & 20 \\
\hline Vitamin + mineral premix $\uparrow$ & 15 & 15 & 15 & 15 & 15 & 15 \\
\hline
\end{tabular}

* The diets were supplemented with DL- $\alpha$-tocopheryl acetate at $(\mathrm{mg} / \mathrm{kg}): 0$ diets 1 and 3, 20 diets 2,4 and 5 from day 0 to day 28 then supplementation increased from 20 to $50 \mathrm{mg} / \mathrm{kg}$ from day 29 to day 56 .

$\dagger$ For details, see Table 1 .

SO used for Expt 2 was stripped of vitamin E by a method based on that of Mohri $e t$ al. (1983). The $\alpha$-tocopherol concentration of SO was reduced from about $400 \mathrm{mg} / \mathrm{l}$ to between 20 and $30 \mathrm{mg} / 1$.

\section{Sample collections}

Faeces and urine. In Expt 1 faeces and urine samples were collected daily for $5 \mathrm{~d}$ at days $8-12,29-33$ and $50-54$ of the experiment. The faeces was obtained from a sloping tray which allowed the urine to drip into a bucket containing $25 \mathrm{ml} 6 \mathrm{M}-\mathrm{HCl}$. The urine was weighed and approximately $60 \mathrm{ml}$ retained. All faeces and urine were stored at $-20^{\circ}$ immediately after collection. The bulked faecal sample was subsequently dried in a fanforced oven at $105^{\circ}$, ground through a $1 \mathrm{~mm}$ screen and a $20 \mathrm{~g}$ subsample was taken and stored at room temperature for analysis.

Blood. Blood samples were collected by jugular vein puncture, with sodium heparin used as an anticoagulant. Duplicate whole-blood samples were used for the TBA-reaction test 
and for the determination of haemoglobin $(\mathrm{Hb})$ and enzymes. The remainder of each sample was centrifuged at $3000 \mathrm{rev} . / \mathrm{min}$ for $10 \mathrm{~min}$. The plasma was then separated and stored at $-20^{\circ}$.

Tissues. At the end of each experiment, pigs were anaesthetized and then killed. Samples (approximately $20 \mathrm{~g}$ ) of liver, heart, longissimus dorsi muscle, kidney and fat tissue from back fat were excised from each pig and stored at $-20^{\circ}$ for later vitamin $\mathrm{E}$ analysis.

Exhaled gases. In the first experiment the exhaled-gas collecting apparatus consisted of a polyvinyl mask, unidirectional inspiratory valve (CIG Medishield, Melbourne, Australia), $\mathrm{CO}_{2}$ absorber (CIG Medishield), $500 \mathrm{ml}$ sample bottle (Alltech Inc, Deerfield, USA) and connecting tubing. When a sample was being collected the pig was held still and the mask sealed around its snout by hand. The unidirectional inspiratory valve was attached to the mask and allowed exhaled gases to pass through the $\mathrm{CO}_{2}$ absorber and sample bottle, and outside air to go to the pig. $\mathrm{CO}_{2}$ and water in exhaled gases were removed by soda lime in the $\mathrm{CO}_{2}$ absorber. The unidirectional inspiratory valve to the $\mathrm{CO}_{2}$ absorber and from the $\mathrm{CO}_{2}$ absorber to the sample bottle were connected with $20 \mathrm{~mm} \times 1 \mathrm{~m}$ latex tubing and $5 \mathrm{~mm} \times 100 \mathrm{~mm}$ polyvinyl tubing respectively. The other end of the sample bottle was immersed in water. The gas-sample collection time was exactly $3 \mathrm{~min}$ after the first bubble appeared from the sample bottle, and then the sample was immediately analysed for hydrocarbons.

The collection procedure used in Expt 1 was stressful and was difficult to undertake when handling bigger pigs. Therefore, the procedure used in the second experiment was modified. Pigs were placed in an air-tight box constructed from $5 \mathrm{~mm}$-thick Perspex and sealed by adhesives. The size of the box was $400 \mathrm{~mm}$ wide $\times 600 \mathrm{~mm}$ long $\times 400 \mathrm{~mm}$ high for pigs from 5 to $13 \mathrm{~kg}$ body weight and $500 \mathrm{~mm}$ wide $\times 900 \mathrm{~mm}$ long $\times 680 \mathrm{~mm}$ high for pigs over $13 \mathrm{~kg}$. A small electric fan (150 mm diameter) was installed underneath the top side of the box to circulate air. A perforated Perspex platform sustained by two plastic plates was provided to separate the animal from urine and faeces. Two access ports were present in the box: an outlet port in front of the animal and inlet port behind. Air from the outlet port of the box was passed through a series of traps containing granular drieritte $(0.8-2 \mathrm{~mm}$, for water, Drieritte Company, Ohio, USA), $50 \mathrm{ml} \mathrm{H}_{2} \mathrm{SO}_{4} / 1$ (for $\mathrm{NH}_{3}$ ) and $100 \mathrm{ml} \mathrm{KOH} / 1$ (for $\mathrm{CO}_{2}$ ). The box and traps were connected with polyvinyl tubing which allowed flexibility in the system and was relatively impermeable to hydrocarbons. A Clements vacuum pump (H. I. Clements Pty Ltd, Sydney, Australia) circulated the air through the box and a series of traps. A ' $Y$ '-shape connector was placed in the tubing line at the inlet to the box to allow $\mathrm{O}_{2}$ to enter from a glass bottle $\left(\mathrm{O}_{2}\right.$ reservoir) and also to maintain a closed system at ambient pressure. In this closed system it was found that leakage of ethane and pentane was about $2 \%$ in $2 \mathrm{~h}$ and $5 \%$ in $4 \mathrm{~h}$. The temperature inside the box was maintained at $22-25^{\circ}$ by spreading ice on the top of the box. A $500 \mathrm{ml}$ sample bottle was placed in the tubing line between the vacuum and the drieritte container. The sample bottle was removed $15-30 \mathrm{~min}$ after placing the pigs in the box, and the sample was immediately analysed for hydrocarbons.

\section{Analyses}

Vitamin $E$. $\alpha$-Tocopherol concentrations in plasma, tissues and feeds were determined by HPLC with fluorescence detection after extraction of samples.

The plasma sample $(1 \mathrm{ml})$ was mixed with an equal volume of absolute ethanol in a Pyrex tube, and light petroleum (b.p. $40-70^{\circ}$ ) was then added. The mixture was shaken for 3 min, allowed to settle for $10 \mathrm{~min}$, and shaken again for $3 \mathrm{~min}$. After settling, a portion of the light petroleum phase was measured accurately and evaporated to dryness under vacuum. The residue was dissolved in a suitable volume of methanol $(0.5-1 \mathrm{ml})$. 
The extraction of vitamin $\mathrm{E}$ from tissue samples was based on the method described by Bayfield \& Romalis (1979). The procedure to extract vitamin E from feed samples was the same as that for tissues, but before the addition of the saponification reagent the finelyground feed samples $(0.5 \mathrm{~g})$ were moistened with distilled water $(1 \mathrm{ml})$.

Analysis of $\alpha$-tocopherol was carried out by injecting a portion $(10 \mu \mathrm{l})$ of methanol solution onto a $3.9 \mathrm{~mm} \times 150 \mathrm{~mm}$ Nova-pak ${ }^{\circledR} \mathrm{C}_{18}$ reverse-phase column (Millipore ${ }^{\circledR} \mathrm{Co}$, Milford, USA). Methanol was used as the eluting solvent at a flow-rate of $2 \mathrm{ml} / \mathrm{min}$ for isocratic elution. The HPLC system consisted of a Waters Millipore liquid chromatography 6000A pump model, fitted with a Waters WISP 710B Auto Sampler (Millipore Co.). The effluent was monitored using a Hitachi F1000 Fluorescence Spectrophotometer (Hitachi Co., Mito, Japan) with excitation and emission wavelengths of 295 and $340 \mathrm{~mm}$ respectively. The duration of the chromatographic analysis was about 6 min. The chromatographic peak was identified by comparison of the retention time with a pure standard of $\alpha$-tocopherol (F. Hoffman-La Roche Co. Ltd, Basel, Switzerland) and the concentration of vitamin $\mathrm{E}$ in samples was calculated from peak height with the knownconcentration standard solution as the reference. The standard solution was run in triplicate before a new batch of samples and, thereafter, once every five samples.

$T B A$ reaction assay of erythrocytes and feed samples. The assay of TBA-reactive substances in porcine RBC was based on the method of described by Fontaine \& Valli (1977), with minor modification. Freshly-collected blood $(0.5 \mathrm{ml})$ was used for preparing RBC suspensions. The TBA-reactive substance was expressed as $\mu \mathrm{mol}$ malondialdehyde (MDA)/100 g Hb.

For quantitative determination of TBA-reactive substances, 1,1,3,3-tetraethoxypropane (TEP) was used as the external standard. To prepare the external standard, stock TEP (97-98\%, purity, Sigma Chemical Co., St Louis, MO, USA) was diluted with distilled water to make a standard solution containing $61 \mu \mathrm{mol}$ TEP/1. For each assay a standard curve was made using a few tubes containing the same amounts of fresh blood, as those for the TBA-reaction assay and these were subjected to the same assay procedure. Before the incubation, various amounts of the standard solution $(0.05,0 \cdot 1,0.2$ and $0.4 \mathrm{ml}$ respectively) were added and mixed with the RBC suspension. After reading the results a standard curve for the MDA complex was prepared. The contents of TBA-reactive substances in RBC induced by $\mathrm{H}_{2} \mathrm{O}_{2}$ were calculated as MDA equivalents from the standard curve.

Since pigs on diet 3 of Expt 2 were observed to eat less and grow more slowly than other pigs, samples of diets in Expt 2 were collected and dietary oxidative values were measured according to the method described by Tarladgis et al. (1960). Rancidity values of feeds were expressed as $\mu \mathrm{mol} \mathrm{MDA} / \mathrm{kg}$ diet.

Ethane and pentane in exhaled gases. A Shimadsu GC-7A gas chromatograph (Shimadsu Co., Kyoto, Japan) with an ionization detector and fitted with a six-way gas sample valve was employed for chromatographic analysis of hydrocarbon gases. A stainless-steel column $(32 \mathrm{~mm} \times 1.8 \mathrm{~m})$ filled with activated alumina $(80-100 \mathrm{mesh})$ was used with $\mathrm{N}_{2}$ carrier gas, flow-rate $28 \mathrm{ml} / \mathrm{min}$. The chromatographic peaks of samples were recorded using a Spectro-Physics integrator (Model SP4270; Spectro-Physics, California, USA). The temperature of the detector and injector was $265^{\circ}$, and the column temperature was programmed as $50^{\circ}$ for $1 \mathrm{~min}$ and then raised by $16^{\circ} / \mathrm{min}$ to $250^{\circ}$ which was held for $5 \mathrm{~min}$. Between sample application and after each day's analyses the column and alumina sample loop, which is described later (pp. 85-86), were held at $250^{\circ}$ to remove any high-molecularweight hydrocarbons.

Since the concentrations of ethane and pentane were very low in gas samples, it was necessary to concentrate the sample before injecting it onto the column. A length of brass tubing ( $3.2 \mathrm{~mm} \times 125 \mathrm{~mm}$ ) was attached with an adaptor fitted to the inlet port of a six-way 
gas sample valve which was mounted on the side of the gas chromatograph. A stainlesssteel sample loop $(3.2 \mathrm{~mm} \times 105 \mathrm{~mm})$ containing activated alumina ( $80-100 \mathrm{mesh})$ was connected to the brass tubing. During sample transfer from the sample bottle this loop was immersed in an icy slush of acetone-liquid $\mathrm{N}_{2}$ until the sample was injected into the gas chromatograph. Perspex tubing $(25 \mathrm{~mm} \times 90 \mathrm{~mm})$ containing granual drieritte $(0.8-2.0 \mathrm{~mm}$ mesh) was connected to the other end of the sample loop by polyvinyl tubing $(5 \mathrm{~mm} \times 50 \mathrm{~mm})$. The outlet port of the sample valve was attached to a small Clements vacuum pump (H. I. Clements Pty Ltd) with adjustable evacuation pressure.

When the sample was analysed, one side of the $500 \mathrm{ml}$ sample bottle was connected to the Perspex tubing, and the other side was immersed in water. The gas sample in the sample bottle was drawn into the sample loop by the vacuum pump. A $100 \mathrm{ml}$ flask containing $90 \mathrm{ml} \mathrm{H}_{2} \mathrm{SO}_{4}(50 \mathrm{ml} / 1)$ was placed between the Perspex tubing and the sample bottle to trap any $\mathrm{NH}_{3}$ in the sample. After the sample bottle was filled with water the acetone-liquid $\mathrm{N}_{2}$ was removed from the sample loop, the $\mathrm{N}_{2}$ flow to the gas chromatograph was diverted through the loop via the six-way sample valve, and a hot water-bath (about $90^{\circ}$ ) was placed around the loop for a 3 min injection period. The $\mathrm{N}_{2}$ flow was then diverted from the sample loop directly onto the chromatographic column. Drieritte in the Perspex tubing and the $\mathrm{H}_{2} \mathrm{SO}_{4}$ solution were replaced for each sample.

Standard ethane $(1 \cdot 1 \mu \mathrm{l} / \mathrm{l})$ and pentane $(2.7 \mu \mathrm{l} / \mathrm{l})$ gases balanced in $\mathrm{N}_{2}$ were purchased from CIG Ltd, Melbourne, Australia. A standard curve was obtained by injecting various amounts of standard gases $(0.5-3 \mathrm{ml})$ onto the column via the sample bottle. Chromatographic peaks of samples were identified by comparison with the retention time of the standard gases. Before and after collection each day, duplicate $500 \mathrm{ml}$ air samples from the pig house were collected and analysed to determine the background level of hydrocarbon gases. Ethane and pentane contents in exhaled samples were calculated by measuring the peak area, and adjusting for background levels. Although the same chromatographic procedure was used for both experiments, the pentane peak in most samples for Expt 2 was unreadable due to the interference by the baseline rising simultaneously with the pentane peak. Therefore, pentane values are not reported for Expt 2.

The collection procedure for exhaled gases in Expt 1 used an open system with a defined period of time $(3 \mathrm{~min})$. The ethane and pentane concentrations were expressed, therefore, as pmol/1. In Expt 2 a closed system was used for the collection of exhaled gases, which allowed the production rate of exhaled hydrocarbons of pigs to be measured. The collection period of time varied for different pigs (from 15 to $30 \mathrm{~min}$ after placing the pigs in the system). Accordingly, for Expt 2 hydrocarbon production rate was expressed as pmol/kg body weight per min.

Haemoglobin. The $\mathrm{Hb}$ concentration of whole blood was determined in duplicate using a Haemoglobin Test-Combination Kit (Boehringer Mannheim, Mannheim, Germany).

Total plasma lipid. The total lipid in plasma was determined calorimetrically in duplicate using a diagnostic kit (Boehringer Mannheim).

Nitrogen. The $\mathbf{N}$ contents of feed $(0.5 \mathrm{~g})$, urine $(1 \mathrm{ml})$ and dried faeces $(0.5 \mathrm{~g})$ samples were determined using a Kjel-Foss automatic analyser (Foss Electric, Hillerod, Denmark). The protein contents of samples were calculated using the factor of 6.25 .

Enzymes. The activity of glutathione peroxidase (EC 1.11.1.9; GSH-Px) in whole blood $(100 \mu 1)$, creatine phosphokinase $(E C 2.7 .3 .2 ; \mathrm{CK})$ and aspartate aminotransferase (EC 2.6.1.1; ASAT) in plasma $(10 \mu \mathrm{l})$ were measured using a Roche Cobas Mira automatic system (F. Hoffman-La Roche Co. Ltd). GSH-Px activity was expressed as $\mu \mathrm{mol}$ NADPH oxidized/min per $\mathrm{g} \mathrm{Hb}$, and $\mathrm{CK}$ and ASAT as unit/ml. 


\section{Statistical procedures}

The experiment was using a randomized complete block design as described by Steel \& Torrie (1980). The data were analysed by ANOVA, and the means were compared by least significant difference for a probability of $P<0.05$.

\section{RESULTS}

\section{Expt 1}

Production performance and health state. Apparent digestibilities of dry matter, bodyweight gains and feed efficiencies were similar for pigs on the various treatments. $\mathrm{N}$ retention was lower $(P<0.05)$ in pigs consuming vitamin E-supplemented diets during the early experimental period, but the differences were not significant after $29 \mathrm{~d}$ on the experimental diets. No clinical signs of vitamin E deficiency were observed in the pigs during the experimental period or at necropsy. The values for plasma CK and ASAT were 743.4 (SE 121.4) and 52.6 (SE 6.5) unit $/ \mathrm{ml}$ respectively at $56 \mathrm{~d}$ of experiment. These values were within the normal range.

Plasma vitamin $E$ concentrations. Plasma $\alpha$-tocopherol concentrations at weaning were similar for all groups and the mean concentration was 1.35 ( $\mathrm{SE} 0.34) \mu \mathrm{g} / \mathrm{ml}$. Values then significantly declined in all treatment groups $(P<0.05) 7 \mathrm{~d}$ after weaning (Fig. 1). The magnitude of the decline in the first week post-weaning was less for pigs supplemented with either 20 or $100 \mathrm{mg}$ vitamin $\mathrm{E} / \mathrm{kg}$ diet than for the pigs not receiving the supplement. In pigs receiving no vitamin E supplement, plasma $\alpha$-tocopherol fell continuously to $0.1 \mu \mathrm{g} / \mathrm{ml}$ within $21 \mathrm{~d}$ and remained low thereafter. Pigs given the vitamin E supplement showed elevated plasma $\alpha$-tocopherol concentrations when compared with controls, after reaching minimum circulating levels of $0.31 \mu \mathrm{g} / \mathrm{ml}$ with diet 2 and $0.36 \mu \mathrm{g} / \mathrm{ml}$ with diet 3 . The timecourse and rate of increase in plasma $\alpha$-tocopherol concentrations were affected by the level of dietary supplementation.

Tissue vitamin E concentrations. Table 3 shows the distribution of $\alpha$-tocopherol in tissues at day 63 of the experiment. The $\alpha$-tocopherol concentrations of tissues differed significantly $(P<0.05)$ between treatment groups, reflecting the supplementation level. With all analysed tissues the highest tocopherol value was found in adipose tissue, while the lowest value was in kidneys.

Thiobarbituric acid-reactive substances of erythrocytes. Data in Table 4 shows that pigs not receiving a vitamin $\mathrm{E}$ supplement had greater levels of TBA-reactive substances $(P<$ $0.05)$ than pigs given the supplemented diet. There was no difference between the two supplemented groups.

Ethane and pentane concentrations in exhaled gases. The effect of dietary vitamin $\mathrm{E}$ on ethane and pentane concentrations in exhaled gases at the end of the experiment is illustrated in Fig. 2. The mean values for ethane and pentane in the unsupplemented group were 177.2 (SE 17.3) and $149 \cdot 3$ (SE 24.0 ) pmol/l respectively. The addition of either 20 or $100 \mathrm{mg}$ vitamin $\mathrm{E} / \mathrm{kg}$ to the diet significantly depressed the concentration of hydrocarbons $(P<0.05)$. Although pigs on the diet supplemented with $20 \mathrm{mg}$ vitamin $\mathrm{E} / \mathrm{kg}$ had somewhat higher ethane and pentane concentrations than those supplemented with $100 \mathrm{mg}$ vitamin $\mathrm{E} / \mathrm{kg}$, the difference was not statistically significant $(P>0.4$ for ethane and $P>0.2$ for pentane).

Total plasma lipid concentrations and blood glutathione peroxidase activity. There was an increase in plasma lipid concentrations $(P<0.05)$ with age up to $42 \mathrm{~d}$ on the experimental diets. However, vitamin $\mathrm{E}$ supplementation of diets did not affect the plasma lipid level. The activity of GSH-Px also increased significantly with age $(P<0.05)$ during the first $21 \mathrm{~d}$ 


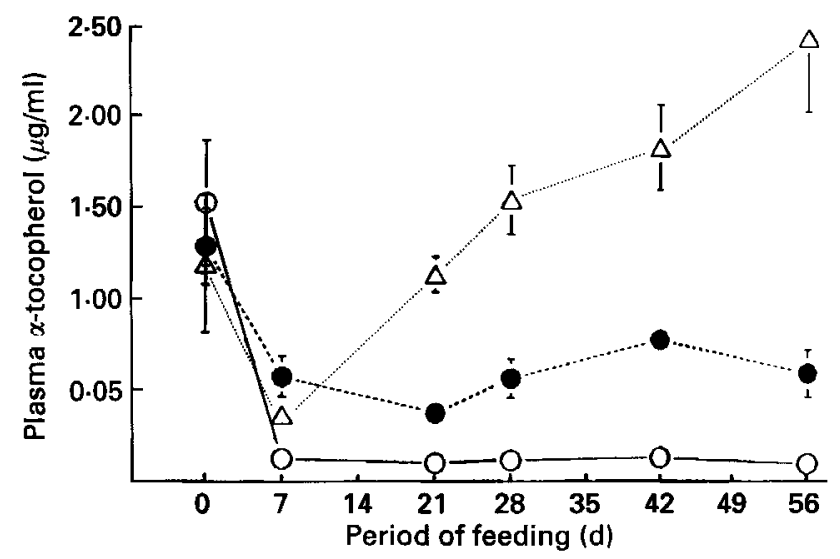

Fig. 1. Expt 1. Plasma $\alpha$-tocopherol concentrations of pigs fed on diets supplemented with three levels of vitamin E. (O), Without vitamin E; (๑), $20 \mathrm{mg}$ DL- $\alpha$-tocopheryl acetate $/ \mathrm{kg} ;(\triangle), 100 \mathrm{mg}$ DL- $\alpha$-tocopheryl acetate $/ \mathrm{kg}$. For details of diets and procedures, see Table 1 and pp. 82-85. Values are means with their standard errors represented by vertical bars.

Table 3. Expt 1. Tissue $\alpha$-tocopherol concentrations ( $\mu \mathrm{g} / \mathrm{g}$ wet tissue) at day 63 of the experiment for pigs fed on diets supplemented with three levels of vitamin $E^{*}$

\begin{tabular}{|c|c|c|c|c|}
\hline \multirow[b]{2}{*}{ Vitamin E supplement (mg/kg diet) ... } & \multicolumn{4}{|c|}{$\begin{array}{l}\text { Tissue } \alpha \text {-tocopherol } \\
\text { concentration }(\mu \mathrm{g} / \mathrm{g})\end{array}$} \\
\hline & 0 & 20 & 100 & SEM \\
\hline Liver & $0 \cdot 13^{\mathrm{a}}$ & $1 \cdot 41^{\mathrm{b}}$ & $5 \cdot 24^{\mathrm{c}}$ & $0 \cdot 21$ \\
\hline Heart & $0 \cdot 39^{\mathrm{a}}$ & $3 \cdot 20^{b}$ & $8 \cdot 60^{c}$ & $0 \cdot 31$ \\
\hline Adipose tissue & $1 \cdot 21^{\mathrm{a}}$ & $5 \cdot 11^{b}$ & $16 \cdot 89^{\circ}$ & 0.23 \\
\hline Skeletal muscle & $0.32^{\mathrm{a}}$ & $0.97^{b}$ & $3 \cdot 22^{\mathrm{e}}$ & 0.23 \\
\hline Kidney & nd & $0 \cdot 55^{\mathrm{a}}$ & $1.89^{\mathrm{b}}$ & $0 \cdot 04$ \\
\hline
\end{tabular}

$a, b, c$ Means within a row with different superscript letters were significantly different $(P<0.05)$. nd, Not detected.

* For details of diets and procedures, see Table 1 and pp. 82-87.

Table 4. Expt 1. Concentrations of thiobarbituric acid (TBA)-reactive substances for erythrocytes from pigs fed on diets supplemented with three levels of vitamin $E^{*}$

\begin{tabular}{ccccc}
\hline & \multicolumn{3}{c}{$\begin{array}{c}\text { TBA-reactive substances } \\
(\mu \text { mol MDA/100 g Hb) }\end{array}$} \\
\cline { 2 - 5 } Day of experiment... & 35 & 42 & 49 & 56 \\
\hline Vitamin E supplement (mg/kg diet) & & & & \\
0 & $15 \cdot 81^{\mathrm{b}}$ & $12 \cdot 42^{\mathrm{b}}$ & $11 \cdot 84^{\mathrm{b}}$ & $14 \cdot 23^{\mathrm{b}}$ \\
20 & $8 \cdot 39^{\mathrm{a}}$ & $8.65^{\mathrm{a}}$ & $9 \cdot 21^{\mathrm{a}}$ & $9 \cdot 14^{\mathrm{a}}$ \\
100 & $9 \cdot 21^{\mathrm{a}}$ & $9 \cdot 23^{\mathrm{a}}$ & $8 \cdot 26^{\mathrm{a}}$ & $9 \cdot 25^{\mathrm{a}}$ \\
SEM & $1 \cdot 06$ & $0 \cdot 48$ & $0 \cdot 40$ & $0 \cdot 80$ \\
\hline
\end{tabular}

a,b Means within columns with different superscript letters were significantly different $(P<0 \cdot 05)$.

MDA, malondialdehyde; $\mathrm{Hb}$, haemoglobin.

* For details of diets and procedures, see Table 1 and pp. 82-87. 


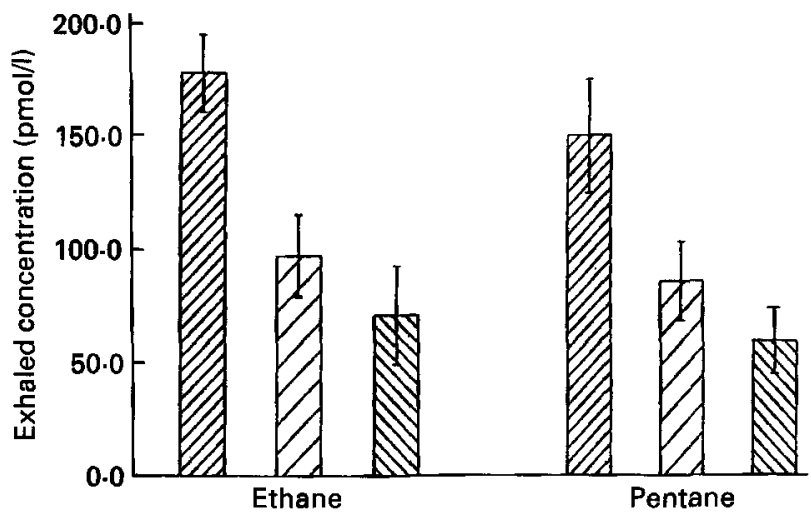

Fig. 2. Expt 1. Ethane and pentane production in exhaled gases at day 56 for pigs fed on diets supplemented with three levels of vitamin E. (四), Without vitamin E; ( $\gtrsim), 20 \mathrm{mg}$ DL- $\alpha$-tocopheryl acetate/kg; $(\mathbb{\nabla}), 100 \mathrm{mg} \mathrm{DL}-\alpha$ tocopheryl acetate $/ \mathrm{kg}$. For details of diets and procedures, see Table 1 and pp. 82-87. Values are means with their standard errors represented by vertical bars.

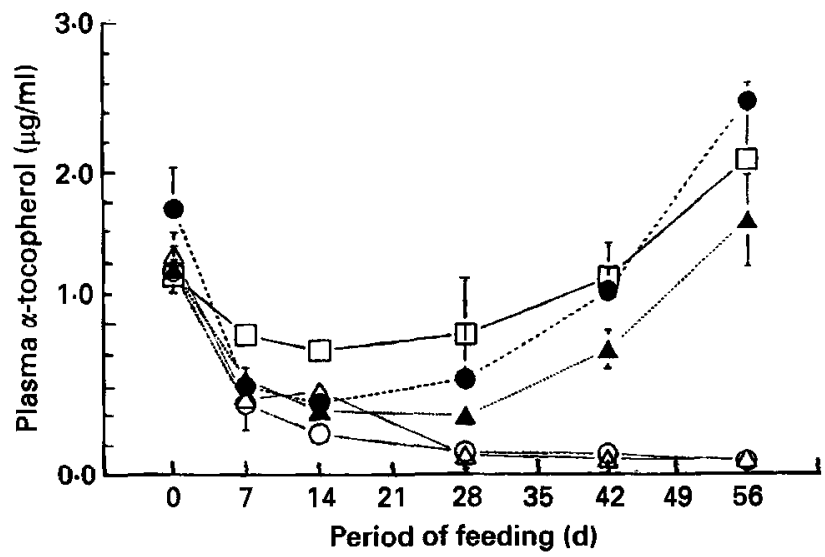

Fig. 3. Expt 2. Effects of dietary vitamin $\mathrm{E}$ and fats on plasma $\alpha$-tocopherol concentrations of pigs. (O), $10 \mathrm{~g}$ sunflower oil (SO) $/ \mathrm{kg}$, without vitamin $\mathrm{E}$ (diet 1);(O), $10 \mathrm{~g} \mathrm{SO} / \mathrm{kg}+$ vitamin $\mathrm{E}($ diet 2$) ;(\triangle), 100 \mathrm{~g} \mathrm{SO} / \mathrm{kg}$, without vitamin E (diet 3), (A), $100 \mathrm{~g} \mathrm{SO} / \mathrm{kg}+$ vitamin E (diet 4); ( $\square$ ) $100 \mathrm{~g}$ tallow $/ \mathrm{kg}+$ vitamin E (diet 5). Diets were supplemented with $\mathrm{DL}$ - $\alpha$-tocopheryl acetate at $(\mathrm{mg} / \mathrm{kg}): 0$ diets 1 and 3,20 diets 2,4 and 5 from day 0 to day 28 , and then supplementation was increased from 20 to $50 \mathrm{mg} / \mathrm{kg}$ from day 29 to day 56 . For details of diet composition and procedures, see Table 2 and pp. 82-85. Values are means with their standard errors represented by vertical bars.

of the experiment. No differences in GSH-Px activities were found between various treatment groups.

\section{Expt 2}

Production performance. Pigs fed on $100 \mathrm{~g} \mathrm{SO} / \mathrm{kg}$ diet without vitamin E supplementation had lower feed intakes and body-weight gains $(P<0.05)$ than the other treatment groups. This may be due in part to the high oxidative value of this diet, since results showed that both diets 3 and 4 had been partially oxidized for the first $14 \mathrm{~d}$, and the oxidation of diet 3 was more than 2-fold greater than that of diet 4 (the value for diet 4 was also 2-fold higher than other diets). Higher oxidation values were found also in diets 3 and 4 compared with diet 5 when sampled on other occasions. Increased oxidation values may result in decreased palatability of the feed. No clinical signs of vitamin $\mathbf{E}$ deficiency were observed in pigs during the experimental period, or at necropsy. 
Table 5. Expt 2. Effects of dietary vitamin $E$ and fats on tissue $\alpha$-tocopherol concentrations for pigs at day 63 of the experiment*

\begin{tabular}{|c|c|c|c|c|c|c|}
\hline \multirow[b]{2}{*}{ Diet no.†.... } & \multicolumn{6}{|c|}{$\begin{array}{l}\text { Tissue } \alpha \text {-tocopherol concentration } \\
(\mu \mathrm{g} / \mathrm{g} \text { wet } \mathrm{wt})\end{array}$} \\
\hline & 1 & 2 & 3 & 4 & 5 & SEM \\
\hline Liver & $0.47^{\mathrm{a}}$ & $12 \cdot 43^{\mathrm{e}}$ & $0 \cdot 34^{\mathrm{a}}$ & $9 \cdot 87^{\mathrm{b}}$ & $10 \cdot 35^{\mathrm{be}}$ & 0.82 \\
\hline Heart & $0.61^{a}$ & $12 \cdot 70^{\mathrm{b}}$ & $0 \cdot 41^{\mathrm{a}}$ & $10 \cdot 45^{\mathrm{b}}$ & $10 \cdot 42^{\mathrm{b}}$ & 0.74 \\
\hline Adipose tissue & $1 \cdot 20^{\mathrm{b}}$ & $13 \cdot 13^{c}$ & $0.62^{\mathrm{a}}$ & $8.71^{\mathrm{b}}$ & $11.58^{\mathrm{e}}$ & 0.92 \\
\hline Muscle & $0.29^{a}$ & $4.49^{\circ}$ & $0 \cdot 19^{\mathrm{a}}$ & $3 \cdot 01^{\mathrm{b}}$ & $3 \cdot 23^{b}$ & 0.28 \\
\hline Kidney & nd & $4 \cdot 32$ & nd & 3.60 & $3 \cdot 73$ & 0.47 \\
\hline
\end{tabular}

${ }^{a, b, c}$ Means within a row with different superscript letters were significantly different $(P<0.05)$. nd, Not detectable.

* For details of diet composition and procedures, see Table 2 and pp. 82-87.

$\dagger$ Diets were supplemented with DL- $\alpha$-tocopheryl acetate at $(\mathrm{g} / \mathrm{kg}): 0$ diets 1 and 3, 20 diets 2,4 and 5 from day 0 to day 28 , and then supplementation was increased from 20 to $50 \mathrm{mg} / \mathrm{kg}$ from day 29 to day 56 . Diets 1 and 2 contained $10 \mathrm{~g}$ sunflower oil (SO) $/ \mathrm{kg}$, diets 3 and $4100 \mathrm{~g} \mathrm{SO} / \mathrm{kg}$, diet $5100 \mathrm{~g}$ tallow $/ \mathrm{kg}$.

Concentrations of $\alpha$-tocopherol in plasma and tissues. The plasma $\alpha$-tocopherol concentrations of pigs in various treatment groups are presented in Fig. 3. At the beginning of the experiment they were almost identical for all treatment groups, and then declined during the first $14 \mathrm{~d}$ after weaning. Subsequently, plasma tocopherol concentrations rose in pigs supplemented with vitamin $\mathrm{E}$, but not in the pigs fed on $100 \mathrm{~g} \mathrm{SO} / \mathrm{kg}$ diet when vitamin E was supplemented at $20 \mathrm{mg} / \mathrm{kg}$. Vitamin E supplementation at $50 \mathrm{mg} / \mathrm{kg}$ in diets resulted in a significant increase in plasma $\alpha$-tocopherol concentrations in pigs in all groups. Pigs on $10 \mathrm{~g} \mathrm{SO} / \mathrm{kg}$ diet with vitamin $\mathrm{E}$ (diet 2$)$ had significantly higher $(P<0.05)$ plasma $\alpha$-tocopherol concentrations after $42 \mathrm{~d}$ of the experiment than those on the diet containing $100 \mathrm{~g} \mathrm{SO} / \mathrm{kg}$ (diet 4). For pigs not receiving the vitamin $\mathrm{E}$ supplement, plasma $\alpha$-tocopherol concentrations declined throughout the experiment.

The $\alpha$-tocopherol concentration in tissues was significantly higher $(P<0.05)$ in pigs on the vitamin E-supplemented diets than in those fed on unsupplemented diets (Table 5). When diets were supplemented with vitamin $\mathrm{E}$ the $\alpha$-tocopherol concentrations in liver, fat and muscle were significantly greater in the pigs on $10 \mathrm{~g} \mathrm{SO} / \mathrm{kg}$ than in those on $100 \mathrm{~g} \mathrm{SO} / \mathrm{kg}$. In pigs fed on the diet containing $100 \mathrm{~g}$ tallow $/ \mathrm{kg}$, tissue $\alpha$-tocopherol concentrations tended to be higher than that for pigs fed on the diet containing $100 \mathrm{~g} \mathrm{SO} / \mathrm{kg}$, and the difference was significant $(P<0.05)$ for adipose tissue. In pigs fed on the unsupplemented diets, tissue $\alpha$-tocopherol concentrations tended to decrease with increasing SO intake, and a significantly lower concentration was found in adipose tissue in the pigs on $100 \mathrm{~g} \mathrm{SO} / \mathrm{kg}$ compared with those on $10 \mathrm{~g} \mathrm{SO} / \mathrm{kg}(P<0.05)$.

Lipid peroxidation status. During the first $28 \mathrm{~d}$ of the experiment the levels of TBAreactive substances of RBC were significantly lower $(P<0.05)$ in pigs supplemented with $20 \mathrm{mg}$ vitamin $\mathrm{E} / \mathrm{kg}$ diet than in pigs receiving unsupplemented diets (Table 6). However, the levels of TBA-reactive substances were not depressed by dietary vitamin $E$ supplementation at the level of $20 \mathrm{mg} / \mathrm{kg}$ diet when the diet contained $100 \mathrm{~g} \mathrm{SO} / \mathrm{kg}$. When diets contained $50 \mathrm{mg}$ vitamin $\mathrm{E} / \mathrm{kg}$ no significant difference in TBA-reactive substances was found between groups. For pigs on the unsupplemented diets, TBA-reactive substances increased continuously with age, and pigs on the diet with $100 \mathrm{~g} \mathrm{SO} / \mathrm{kg}$ (diet 3 ) had greater $(P<0.05)$ levels of TBA-reactive substances than those on the $10 \mathrm{~g} \mathrm{SO} / \mathrm{kg} \operatorname{diet}($ diet 1$)$ after $42 \mathrm{~d}$ of the experiment. 
Table 6. Expt 2. Effect of dietary vitamin $E$ and fats on thiobarbituric acid (TBA)reactive substances in erythrocytes and ethane production in exhaled gases of pigs*

\begin{tabular}{|c|c|c|c|c|c|c|}
\hline \multirow{2}{*}{$\begin{array}{c}\text { Day of } \\
\text { experiment }\end{array}$} & \multicolumn{5}{|c|}{ Diet no. $\dagger$} & \multirow[b]{2}{*}{ SEM } \\
\hline & 1 & 2 & 3 & 4 & 5 & \\
\hline \multicolumn{7}{|c|}{ TBA-reactive substances ( $\mu \mathrm{mol} \mathrm{MDA} / 100 \mathrm{~g} \mathrm{Hb}$ ) } \\
\hline 14 & $18 \cdot 70^{\mathrm{h}, \mathrm{c}}$ & $3.45^{2}$ & $5.07^{\mathrm{a}}$ & $27 \cdot 43^{\mathrm{c}}$ & $7 \cdot 48^{\mathrm{ab}}$ & 3.88 \\
\hline 28 & $24 \cdot 46^{\mathrm{b}}$ & $7 \cdot 07^{\mathrm{a}}$ & $25 \cdot 56^{\mathrm{b}}$ & $28 \cdot 88^{b}$ & $5 \cdot 77^{\mathrm{a}}$ & $4 \cdot 78$ \\
\hline 42 & $29 \cdot 15^{\mathrm{b}}$ & $9 \cdot 08^{\mathrm{a}}$ & $42 \cdot 96^{\mathrm{c}}$ & $10 \cdot 66^{\mathrm{a}}$ & $9 \cdot 32^{\mathrm{a}}$ & $2 \cdot 59$ \\
\hline 56 & $27 \cdot 79^{\mathrm{b}}$ & $8 \cdot 80^{\mathrm{a}}$ & $40 \cdot 87^{\mathrm{c}}$ & $9 \cdot 49^{\mathrm{a}}$ & $9 \cdot 53^{\mathrm{a}}$ & 0.89 \\
\hline \multicolumn{7}{|c|}{ Ethane level in exhaled gases (pmol/1 per $\mathbf{k g}$ body wt per min) } \\
\hline 14 & $4 \cdot 64^{\mathrm{b}}$ & $2 \cdot 35^{\mathrm{a}}$ & $4.45^{\mathrm{b}}$ & $8 \cdot 19^{\mathrm{c}}$ & $3 \cdot 38^{\mathrm{ab}}$ & 0.68 \\
\hline 28 & $5 \cdot 20^{\mathrm{e}}$ & $2 \cdot 47^{2}$ & $6 \cdot 24^{\mathrm{c}}$ & $4 \cdot 45^{\mathrm{bc}}$ & $2 \cdot 48^{\mathrm{a}}$ & 0.61 \\
\hline 42 & $5 \cdot 78^{\mathrm{b}}$ & $1.86^{\mathrm{a}}$ & $6.07^{\mathrm{b}}$ & $2 \cdot 12^{\natural}$ & $2 \cdot 34^{\mathrm{a}}$ & 0.25 \\
\hline 56 & $3 \cdot 08^{b}$ & $1 \cdot 64^{a}$ & $3.72^{\mathrm{b}}$ & $1 \cdot 20^{\mathrm{a}}$ & $1 \cdot 18^{\mathrm{a}}$ & 0.27 \\
\hline
\end{tabular}

a.b.c Means within a row with different superscript letters were significantly different $(P<0.05)$.

MDA, malondialdehyde; Hb, haemoglobin.

* For details of diet composition and procedures, see Table 2 and pp. 82-87.

$\dagger$ Diets were supplemented with DL- $\alpha$-tocopheryl acetate at $(\mathrm{g} / \mathrm{kg}): 0$ diets 1 and 3,20 diets 2,4 and 5 from day 0 to day 28 and then supplementation was increased from 20 to $50 \mathrm{mg} / \mathrm{kg}$ from day 29 to day 56 . Diets 1 and 2 contained $10 \mathrm{~g}$ sunflower oil (SO) $/ \mathrm{kg}$, diets 3 and $4100 \mathrm{~g} \mathrm{SO} / \mathrm{kg}$, diet $5100 \mathrm{~g}$ tallow $/ \mathrm{kg}$.

Data in Table 6 show that there were significant differences $(P<0.05)$ in ethane production in exhaled gases of pigs fed on the different diets. Ethane production was significantly higher $(P<0.05)$ in pigs when diets were not supplemented with vitamin $\mathrm{E}$ compared with vitamin E-supplemented diets. A high level of ethane production was found also in pigs given a $100 \mathrm{~g} \mathrm{SO} / \mathrm{kg}$ diet supplemented with $20 \mathrm{mg}$ vitamin $\mathrm{E} / \mathrm{kg}$ (diet 4). When supplementation of vitamin $\mathrm{E}$ was increased from 20 to $50 \mathrm{mg} / \mathrm{kg}$ diet, dietary fat had no effect on ethane production.

\section{DISCUSSION}

At weaning, pigs are most susceptible to the development of vitamin E deficiency. Thus, knowledge of the requirement of pigs for vitamin $E$ at this stage is particularly important. Data in both Expts 1 and 2 showed that the plasma vitamin E status in piglets declined soon after weaning. This finding may help to explain why diseases associated with vitamin $E$ deficiency often occur in weaners. A similar trend has been demonstrated also by other investigators (Mahan \& Moxon, 1980; Meyer et al. 1981; Bonnette et al. 1990). The decrease in plasma vitamin $\mathrm{E}$ concentrations may be associated with low feed intake (Peplowski et al. 1981) and/or poor absorption efficiency for vitamin E. Results in Expt 1 indicated that plasma lipid concentrations increased with age up to $42 \mathrm{~d}$ after weaning, which suggests that digestibility or absorption of dietary fat at weaning may not be as effective as at a later age. Because of the fat-soluble characteristic of vitamin $E$ the absorption of this vitamin is dependent on the animal's ability to digest and absorb fat (Wiss et al. 1962). When the diet was supplemented with vitamin E, plasma vitamin $\mathrm{E}$ concentrations rose in proportion to the dietary intake. However, it appears that even with a dietary vitamin $E$ supplement as high as $100 \mathrm{mg} / \mathrm{kg}$ diet it took about $14-21 \mathrm{~d}$ before the full effect on vitamin $E$ concentrations in plasma was seen. This suggests that 
supplementation of weaner diets with vitamin $\mathrm{E}$ does not effectively prevent a decline in plasma vitamin $\mathrm{E}$ in weaners.

In many studies of vitamin $\mathrm{E}$ requirements of pigs, clinical signs of deficiency or mortality are the usual assessment criterion, and most recommended levels are based on the amount of vitamin $E$ needed to prevent gross signs of deficiency. However, the occurrence of clinical signs of deficiency may vary according to the experimental conditions and the genotype of the pig, which may in turn indicate different requirements. Although the National Research Council (1988) recommended that supplements of 11-16 mg vitamin $\mathrm{E} / \mathrm{kg}$ diet are adequate for preventing mortality and deficiency lesions and for supporting the normal performance in growing pigs, Jensen et al. (1988) observed that $16 \mathrm{mg}$ vitamin $\mathrm{E} / \mathrm{kg}$ diet could not prevent deficiency lesions and mortality of pigs, and they suggested that the supplement level should exceed $30 \mathrm{mg} / \mathrm{kg}$ diet. Interestingly, pigs under the present experimental conditions did not show any clinical vitamin $\mathrm{E}$ deficiency lesions, even when fed on the diet containing less than $2 \mathrm{mg}$ vitamin $\mathrm{E} / \mathrm{kg}$ and $100 \mathrm{~g} \mathrm{SO} / \mathrm{kg}$. In fact, most rations for weaners contain at least $40 \mathrm{mg} / \mathrm{kg}$ and frequently considerably more, but the spontaneous incidence of vitamin $E$ deficiency diseases is still reported $(E$. T. Thornton, personal communication; Nielson et al. 1989). Thus, it seems that the assessment of vitamin E requirements for pigs based on clinical signs or mortality alone may not be appropriate.

Van Vleet (1982) reported that mortality and lesions of vitamin E deficiency developed when vitamin $E$ concentrations in plasma are below $0.4 \mu \mathrm{g} / \mathrm{ml}$, and this value has been used by other investigators as a threshold for deciding whether pigs are deficient in vitamin $\mathrm{E}$ (Rammell et al. 1988). However, in the study of Jensen et al. (1988) it was reported that the mortality and lesions of vitamin E deficiency still occurred in pigs with plasma concentrations above $1 \mu \mathrm{g} / \mathrm{ml}$. By contrast, pigs in the present study did not show any clinical deficiency signs, although plasma vitamin E concentrations were below $0.2 \mu \mathrm{g} / \mathrm{ml}$. In view of these observations, vitamin $E$ concentrations in plasma may not be a sensitive indicator of the adequacy of dietary vitamin $E$ intake.

The primary function of vitamin $\mathrm{E}$ is believed to be the protection of unsaturated lipids in biological membranes from peroxidation. Inadequate protection from vitamin $E$ may result in a chain reaction of lipid peroxidation leading to disruption of normal membrane function, with eventual dissolution of cellular compartmentation. The degraded products of lipid peroxidation include ethane, pentane, MDA, fluorescent substances and other chemiluminescent substances (Slater, 1984). Based on the relationship between vitamin E and lipid peroxidation, it appears that the measurement of lipid peroxidation status in pigs could provide a reliable and accurate index of the vitamin E protection of the animal and, thus, would be a means for establishing the requirement for this nutrient.

The important role of dietary vitamin $\mathrm{E}$ in retarding lipid peroxidation was indicated by the elevated levels of TBA-reactive substances of RBC from pigs fed on the diet without vitamin E supplementation. Although it is believed that the value for the lipid peroxidation product MDA may be overestimated in the TBA-reaction assay, numerous studies have clearly demonstrated that this assay is useful for measuring the peroxidative state of biological systems (Buckingham, 1985; Lee \& Csallany, 1987). Results of other studies in pigs indicate that levels of TBA-reactive substances only change in response to a dietary vitamin E supplement, but not Se (Fontaine \& Valli, 1977; Jensen et al. 1983). In the first experiment of the present study the reactive substances did not differ between the two vitamin E-supplemented groups, implying that dietary supplementation with vitamin $\mathbf{E}$ at 20 or $100 \mathrm{mg} / \mathrm{kg}$ provided equivalent protection for pigs against lipid peroxidation damage. In the second experiment, pigs not supplemented with vitamin $\mathbf{E}$ had higher levels of TBA-reactive substances when fed $100 \mathrm{~g} \mathrm{SO} / \mathrm{kg}$ compared with $10 \mathrm{~g} \mathrm{SO} / \mathrm{kg}$, which suggests the lipid peroxidation is not only affected by dietary vitamin $\mathrm{E}$, but also by the 
level of PUFA in the diet, since SO contains about $700 \mathrm{mg} \mathrm{PUFA} / \mathrm{g}$ (Cera et al. 1988). This was anticipated, as the fatty acid profile of animal tissues is influenced by both quality and quantity of fat fed to animals (Lin et al. 1989); as the level of dietary PUFA increases, more lipid peroxidative products will be generated in tissues if the protection by vitamin $\mathrm{E}$ is inadequate.

The data from both experiments of the present study showed that an increase in exhaled hydrocarbons was found in pigs not supplemented with vitamin $E$ and the outputs of these gases decreased with vitamin E supplementation. This finding followed the pattern of levels of TBA-reactive substances. Since an open system was used for the collection of hydrocarbons in Expt 1 and a closed system in Expt 2, the results from these two experiments were not strictly comparable. The values for exhaled hydrocarbons, together with those for TBA-reactive substance, indicate that pigs fed on unsupplemented diets are deficient in vitamin E. It could be argued that the method of collection of exhaled gases used in the present study may be confounded by background gases from the gastrointestinal tract. Studies in humans (Lemoyne et al. 1987) and rats (Kivits et al. 1981) do not support this view. In the present study the background gases were measured before and after each days's assay, and concentrations of ethane or pentane were calculated by subtracting the background levels. In fact the background level of hydrocarbon gases was constant during the experimental period. Although the procedure for measuring hydrocarbons in exhaled gases was non-invasive, there were some drawbacks involved in the procedures of sample collection and analysis, including complicated collection and sampling apparatus, the storage of sample and the effect of a large volume of sample on the efficiency of the gaschromatography column. Improvements in these aspects would be an advantage in measuring hydrocarbons in exhaled gases as the index of the state of lipid peroxidation and the protection by antioxidants.

Meydani et al. (1987) reported that mice fed on a diet supplemented with unsaturated fat maintained lower plasma and tissue tocopherol concentrations than those fed on diets containing fat with a lower degree of unsaturation. Results in Expt 2 showed that tissue $\alpha$ tocopherol concentrations were highest in the group given $10 \mathrm{~g} \mathrm{SO} / \mathrm{kg}$ diet, followed by those given $100 \mathrm{~g}$ tallow $/ \mathrm{kg}$, and then those given $100 \mathrm{~g} \mathrm{SO} / \mathrm{kg}$ diet. This reflected the differences in the PUFA level between diets as SO and tallow contain PUFA concentrations of about 700 and $200 \mathrm{mg} / \mathrm{g}$ respectively (Cera et al. 1988; Thi-Dinh et al. 1990). Since vitamin $\mathrm{E}$ ( $\alpha$-tocopherol) concentrations in these diets were almost identical, the lower plasma and tissue $\alpha$-tocopherol concentrations in the pigs fed on the $100 \mathrm{~g} \mathrm{SO} / \mathrm{kg}$ diet were not due, therefore, to oxidative loss of tocopherol in the diet, but to enhanced postabsorptive utilization of vitamin $\mathrm{E}$ in the pigs. Absorption studies indicate that the absorption of vitamin $\mathrm{E}$ in pigs is not influenced by the dietary source and amount of fat when the diet contains more than $10 \mathrm{~g}$ fat $/ \mathrm{kg}$ (Wang \& Leibholz, 1990). Thus, enhanced turnover of vitamin $\mathrm{E}$ in pigs is the mechanism for decreased vitamin $\mathrm{E}$ status in pigs with an increased PUFA intake.

Values for both TBA-reactive substances and exhaled hydrocarbons gases in Expt 1 suggest that a supplement of $20 \mathrm{mg}$ DL- $\alpha$-tocopheryl acetate $/ \mathrm{kg}$ diet is adequate for pigs under the present experimental conditions. However, pigs on the diet supplemented with this level of vitamin E and $100 \mathrm{~g} \mathrm{SO} / \mathrm{kg}$ in Expt 2 showed a significant increase in TBAreactive substances and ethane exhalation compared with pigs given the diet containing $10 \mathrm{~g} \mathrm{SO} / \mathrm{kg}$ or $100 \mathrm{~g}$ tallow $/ \mathrm{kg}$. Plasma $\alpha$-tocopherol concentrations in this group of pigs also showed a continuous decline after $14 \mathrm{~d}$ on the experimental diet. These results suggest that dietary vitamin $E$ at this level is inadequate for pigs fed on diets containing $100 \mathrm{~g} \mathrm{SO} / \mathrm{kg}$. Supplementation with $50 \mathrm{mg}$ vitamin $\mathrm{E} / \mathrm{kg}$ diet, however, provided adequate protection against the lipid peroxidation damage. 
It should be noted that SO used in Expt 2 were partially stripped of vitamin $\mathrm{E}$, particularly $\alpha$-tocopherol. Since vegetable oils are rich sources of vitamin E it could be argued that the increased requirement for vitamin $E$ with an increase in dietary PUFA is often met, at least in part, from the oils themselves. Nevertheless, a number of factors need to be considered if the contribution of vitamin $\mathrm{E}$ from oils is to be counted in the dietary vitamin $E$ content. First, the vitamin $E$ content in oils of different origins varies considerably (Speek et al. 1985). Second, the natural form of vitamin $E$ in diets is not stable and significant losses often occur during processing and storage. Recent studies by Dove \& Ewan $(1990,1991)$ reported that excessive addition of trace minerals in pig diets caused rapid destruction of natural forms of vitamin $E$ ( $\alpha$ - and $\gamma$-tocopherols), and the presence of fat in the diet accelerated the loss of this vitamin. Third, some oils contain mainly vitamin $\mathrm{E}$ isomers other than $\alpha$-tocopherol (Speek et al. 1985; Ball, 1988), and these isomers may not make a significant contribution to the total dietary biological activity of vitamin E for pigs (Bieri \& McKenna, 1981).

In conclusion, the present study demonstrated that lipid peroxidation status of pigs is a sensitive index with which to evaluate vitamin $E$ requirements. The vitamin $E$ and lipid peroxidation status of pigs are not only affected by dietary levels of vitamin $E$, but also by dietary PUFA. The requirement for vitamin $\mathrm{E}$ in young pigs increases as PUFA levels in the diet increase; a level of $20 \mathrm{mg}$ vitamin $\mathrm{E} / \mathrm{kg}$ diet is inadequate when the diet contains $100 \mathrm{~g} \mathrm{SO}$ (70 mg PUFA/g)/kg.

This study was conducted at the Department of Animal Science, University of Sydney, and made possible by the financial support of the Pig Research and Development Corporation, Australia. The authors thank Dr G. McIntosh for the assistance with the preparation of this manuscript; Ms R. Smith and Mr J. McClure for technical assistance; Ms J. Healy and Ms L. Romalis for assistance with vitamin E analysis; and Roche Products Pty Ltd, Sydney, for the vitamins.

\section{REFERENCES}

Agricultural Research Council (1981). The Nutrient Requirement of Pigs. Slough: Commonwealth Agricultural Bureaux.

Ball, G. F. M. (editor) (1988). Fat-soluble Vitamin Assay in Food Analysis: A Comprehensive Review. London and New York: Elsevier Applied Science.

Bayfield, R. F. \& Romalis, L. F. (1979). An improved method for the determination of $\alpha$-tocopherol in sheep liver. Analytical Biochemistry 97, 264-268.

Bieri, J. G. \& McKenna, M. C. (1981). Expressing dietary values for fat-soluble vitamins: changes in concepts and terminology. American Journal of Clinical Nutrition 34, 289-295.

Bonnette, E. D., Kornegay, E. T., Lindemann, M. D. \& Hammerberg, C. (1990). Influence of two supplemental vitamin $\mathrm{E}$ levels and weaning age on performance, humoral antibody production and serum cortisol levels of pigs. Journal of Animal Science 68, 1346-1353.

Buckingham, K. W. (1985). Effect of dietary polyunsaturated, saturated fatty acid ratio and dietary vitamin E on lipid peroxidation in rats. Journal of Nutrition 115, $1425-1435$.

Cera, K. R., Mahan, D. C. \& Reinhart, G. A. (1988). Weekly digestibilities of diets supplemented with corn oil, lard or tallow by weanling swine. Journal of Animal Science 66, 1430-1437.

Dove, C. R. \& Ewan, R. C. (1990). Effect of excess dietary copper, iron or zinc on the tocopherol and selenium status of growing pigs. Journal of Animal Science 68, 2407-2413.

Dove, C. R. \& Ewan, R. C. (1991). Effect of trace minerals on the stability of vitamin E in swine grower diets. Journal of Animal Science 69, 1994-2000.

Duthie, G. G., Arthur, J. R., Nicol, F. \& Walker, M. (1989). Increased indices of lipid peroxidation in the stresssusceptible pigs and effect of vitamin E. Research in Veterinary Science 46, 226-230.

Fontaine, M. \& Valli, V. E. (1977). Studies on vitamin E and selenium deficiency in young pigs. II. The hydrogen peroxide hemolysis test and the measure of red cell lipid peroxides as indices of vitamin $\mathrm{E}$ and selenium status. Canadian Journal of Comparative Medicine 41, 52-55.

Jensen, M., Hakkarainen, J., Lindholm, A. \& Jönsson, L. (1988). Vitamin E requirement of growing swine. Journal of Animal Science 66, 3101-3111.

Jensen, P. T., Neilsen, H. E., Danielsen, D. \& Leth, T. (1983). Effect of dietary fat quality and vitamin $E$ on the antioxidant potential of pigs. Acta Veterinaria Scandinavica 24, 135-147. 
Kivits, G. A. A., Ganguli-Swarttouw, M. A. C. R. \& Christ, E. J. (1981). The composition of alkanes in exhaled air of rats as a result of lipid peroxidation in vivo: effects of dietary fatty acids, vitamin $\mathbf{E}$ and selenium. Biochimica et Biophysica Acta 665, 559-570.

Lee, H. S. \& Csallany, A. S. (1987). Measurement of free and bound malondialdehyde in vitamin E-deficiency and -supplement rat liver tissue. Lipids 22, 104 107.

Lemoyne, M., Van Gossum, A., Kurian, R., Ostro, M., Axler, J. \& Jeejeebhoy, K. N. (1987). Breath pentane analysis as an index of lipid peroxidation: a functional test of vitamin E status. American Journal of Clinical Nutrition 46, 267-272.

Lin, C. F., Gray, J. I., Asghar, A., Buckley, D. J., Booren, A. M. \& Flegal, C. J. (1989), Effects of dietary oils and $\alpha$-tocopherol supplementation on lipid composition and stability of broiler meat. Journal of Food Science 54, 1457-1460.

Lindberg, P. \& Orstadius, K. (1961). Production of muscular dystrophy in pigs by feeding cottonseed oil. Acta Veterinaria Scandinavica 2, 226-235.

Mahan, D. C. \& Moxon, A. L. (1980). Effect of dietary selenium and injectable vitamin E-selenium for weanling swine. Nutrition Reports International 21, 829-836.

Marchello, M. J., Cook, N. K., Slanger, W. D., Johnson, V. K., Fischer, A. G. \& Dinusson, W. E. (1983). Fatty acid composition of lean and fat tissues of swine fed various dietary levels of sunflower seed. Journal of Food Science 48, 1331-1334.

Meydani, S. H., Shapiro, A. C., Meydani, M., Macauley, J. B. \& Blumberg, J. B. (1987). Effect of age and dietary fat (fish, corn and coconut oils) on tocopherol status of C57bl/6 Nia mice. Lipids 22, 345-350.

Meyer, W. R., Mahan, D. C. \& Moxon, A. L. (1981). Value of dietary selenium and vitamin E for weaning swine as measured by performance and tissue selenium and glutathione peroxidase activities. Journal of Animal Science 52, 302-310.

Mohri, K., Dohmoto, C., Idesu, H. \& Igarashi, O. (1983). A simple elimination method of vitamin E from vegetable and fish oil for the preparation of vitamin E deficient diet. Journal of Japanese Society of Nutrition and Food Science 36, 122-124.

Moir, D. C. \& Masters, H. G. (1979). Hepatosis dietetica, nutritional myopathy, mulberry heart disease and associated hepatic selenium levels in pigs. Australian Veterinary Journal 55, 360-364.

Nafstad, I. \& Tollersrud, S. (1970). The vitamin E-deficiency syndrome in pigs. I. Pathological changes. Acta Veterinaria Scandinavica 11, 452-480.

National Research Council (1988). Nutrient Requirements of Swine, 9th ed. Washington, DC: National Academy Press.

Nielsen, T. K., Wolstrup, C., Schirmer, A. L. \& Jensen, P. T. (1989). Mulberry heart disease in young pigs without vitamin $\mathrm{E}$ and selenium deficiency. The Veterinary Record 124, 535-537.

Peplowski, M. A., Mahan, D. C., Murray, F. A., Moxon, A. L., Cantor, A. H. \& Ekstrom, K. E. (1981). Effect of dietary and injectable vitamin $\mathrm{E}$ and selenium on weanling swine antigenically challenged with sheep red blood cells. Journal of Animal Science 51, 344-351.

Rammell, C. G., Pearson, A. B. \& Bentley, G. R. (1988). Vitamin E, selenium and polyunsaturated fatty acids in clinically normal grower (9-16 week old) pigs and their feed: their relationship to the vitamin E/selenium deficiency (VESD) syndrome. New Zealand Veterinary Journal 36, 133-137.

Rice, D. A. \& Kennedy, S. (1989). Vitamin E, selenium and polyunsaturated fatty acid concentrations and glutathione peroxidase activity in tissues from pigs with dietetic microangiopathy (mulberry heart disease). American Journal of Veterinary Research 50, 2101-2104.

Slater, T. F. (1984). Free-radical mechanism in tissue injury. Biochemical Journal 222, 1-15.

Speek, A. J., Schrijver, J. \& Schreurs, W. H. P. (1985). Vitamin E composition of some seed oils as determined by high-performance liquid chromatography with fluorometric detection. Journal of Food Science 50, 121-124.

Steel, R. G. D. \& Torrie, J. H. (1980). Principles and Procedures of Statistics: A Biometrical Approach. 2nd ed. New York: McGraw-Hill Inc.

Tappel, A. L. (1980). Vitamin E and selenium protection from in vivo lipid peroxidation. Annals of the New York Academy of Sciences 355, 18-31.

Tarladgis, B. G., Watts, B. M., Younathan, M. T. \& Dugan, L. R. Jr (1960). A distillation method for the quantitative determination of malonaldehyde in rancid foods. Journal of the American Oil Chemists Society 37 , 44-48.

Thi-Dinh, K. L. K., Demarne, Y., Nicolas, C. \& Lhuillery, C. (1990). Effect of dietary fat on phospholipid class distribution and fatty acid composition in rat fat cell plasma membrane. Lipids 25, 278-283.

Van Vleet, J. F. (1982). Comparative efficacy of five supplementation procedures to control selenium-vitamin $\mathrm{E}$ deficiency in swine. American Journal of Veterinary Research 43, 1180-1189.

Van Vleet, J. F. \& Kennedy, S. (1989). Selenium-vitamin E deficiency in swine. Compendium on Continuing Education for the Practicing Veterinarian 11, 662-668.

Wang, Y. H. \& Leibholz, J. (1990). The absorption of vitamin E in growing pigs. Proceedings of the Nutrition Society of Australia 15, 53 .

Wiss, O., Bunnell, R. B. \& Gloor, U. (1962). Absorption and distribution of vitamin $\mathrm{E}$ in the tissue. Vitamins and Hormones 20, 441-456. 